\title{
ANTIMICROBIAL ACTIVITY AND ENZYMES ON SKIN MUCUS FROM MALE AND FEMALE CASPIAN KUTUM (Rutilus frisii kutum Kamensky, 1901) SPECIMENS
}

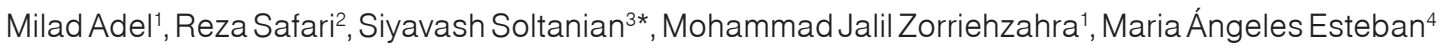 \\ ${ }^{1}$ Department of Aquatic Animal Health and Diseases, Iranian Fisheries Science Research Institute (IFSRI), Agricultural Research Education \\ and Extension Organization (AREEO), Tehran, ${ }^{2}$ Department of Biotechnology, Caspian Sea Ecology Research Center, Iranian Fisheries \\ Science Research Institute (IFSRI), Agricultural Research Education and Extension Organization (AREEO), P.O. Box: 961, Sari, ${ }^{3}$ Aquatic \\ Animal Health \& Diseases Department, School of Veterinary Medicine, Shiraz University, 71441-69155 Shiraz, Iran, ${ }^{4}$ Fish Innate Immune \\ System Group, Department of Cell Biology and Histology, Faculty of Biology, Regional Campus of International Excellence "Campus Mare \\ Nostrum", University of Murcia, 30100 Murcia, Spain \\ *Corresponding author, E-mail: siyavashsoltanian@yahoo.com
}

\begin{abstract}
The mucus layer covering the surface of fish contain a high number of antimicrobial compounds that provide a first line of defense against aquatic pathogens. In the present study, bactericidal activity present on skin mucus of Caspian kutum (Rutilus frisii kutum) broodstock was tested against six pathogenic bacterial strains (Streptococcus iniae, Yersinia ruckeri, Staphylococcus aureus, Listeria monocytogenes, Pseudomonas aeruginosa and Escherichia coli). Furthermore, fungicidal activity was assessed against four pathogenic fungi (Saprolegniasp., Fusarium solani, Candida albicansand Aspergillus flavus). Maximum and minimum antibacterial activity was observed against Y. ruckeri and S. iniae, respectively, while maximum and minimun fungicidal activty was detected against $F$. solaniand $C$. albicans, respectively. Curiously, antimicrobial activity was higher in the fish mucus of female than male against most tested strains. In addition, minimum inhibitory concentration test showed that minimum concentrations of mucus ranged between 125 to $500 \mu \mathrm{g} / \mathrm{L}$ were able to inhibit the growth of the selected bacterial and fungal pathogens. Alkaline phosphatase, lysozyme, protease and esterase activities were also studied on mucus samples being the observed activities very similar between both sexes, although higher lysozyme activity was detected in the mucus offemale fish in comparison to the values recorded on male samples. Skin mucus of this fish species (especially females) could be a potential source of newer and more effective antibacterial components.
\end{abstract}

Key words: Rutilus frisii kutum; skin mucus; bactericidal activity; antifungal activity; fish.

\section{Introduction}

The mucus layer is suggested to be multifunctional by displaying traits and actions important in osmoregulation, reduction of friction between fish and the aquatic environment and disease resistance (1). The major components of the mucus layer are produced by goblet cells. Goblet cells start to differentiate in the basal part of the epidermis, and then grow in size and move towards the surface where they release their content (1). In this

Received: 20 June 2017

Accepted for publication: 7 November 2018 way, the mucus is a dynamic coat, which passively flows over and covers the fish (2).

In fish mucus, the predominant gel-forming macromolecules are glycoproteins called mucins (2). Other known components are involved in fish immunity such as lysozyme, immunoglobulins, complement, carbonic anhydrase, lectins, crinotoxins, calmodulin, flavoenzymes, acute-phase proteins such as C-reactive protein, antimicrobial peptides, Apolipoprotein A-1, peroxidases, trypsin like proteases and proteolytic enzymes like alkaline phosphatase and esterases, among others (3). In previous studies, it has been shown that skin mucus plays an important role in the prevention of colonization 
by parasites, bacteria and fungi $(3,4)$. The antibacterial properties of mucus has been studied in several fish species such as Oncorhynchus mykiss, Plecoglossu altivelis, Scopththalamus maximus, Cyprinus caprio, Catla catla, Labeo rohita, Hypophthalmichthys molitrix and Ctenopharyngodon idella (1, 3, $5,6)$ among others.

Caspian kutum or Caspian white fish is an economically and historically important species in the Caspian sea as well as in Iranian fisheries. It is allocated about 12,500 tons of catching bony fish in 2015 (7). To the best of our knowledge, there is very few available results focus on the immune parameters of this fish species and, curiously, all of them focus on the effects of different dietary components on fish growth, chemical body composition, haematological parameters and humoral immune activities. Among the tested substances are found probiotics such as Bacillus licheniformis and $B$. subtilis (8), prebiotics $(9,10)$, some food additives (e.g. sodium propionate) (11) and even extracts of medicinal plants, such as peppermint (12).

Recently, there is a great interest in applied noninvasive techniques to measure the fish immune status and numerous studies have been carried out to explore the immune activities present in fish mucus $(1,3,5,6,13,14)$. There is a work focused on the comparison of the total protein and lysozyme levels in serum and mucus, being the data obtained for males and females Caspian kutum specimens, in relation with three parameters related to the reproductive period (seasonal temperature, gonadal growth and reproductive migration). Results demonstrated that significant differences were observed in mucus total proteins for male and female specimens (4). Taken into account all these considerations, the main objective of the current study was to know the antimicrobial activity (both bactericidal and fungicidal) and the levels of important enzymes involved in mucosal immunity of skin mucus of Caspian kutum specimens. The results recorded from male and female specimens for the studied activities are discussed.

\section{Materials and methods}

\section{Fish}

A total of 100 Caspian kutum (with the average length of $40 \pm 5 \mathrm{~cm}$ and average weight of $4 \pm 1 \mathrm{~kg}$ ) specimens were captured from Shirood river (west of Mazandaran province, North of Iran) by a local fisherman during reproductive period (in April 2014). Fish were transferred to the laboratory of Fish Diseases at the Caspian Sea Ecology Research Center (Sari, Iran) providing a constant aeration supplied by a portable air pump. The sex and stage of maturity of fish was recognized by the macroscopic examination of the gonads. Female brooders were recognized as stage VI (spawning) maturity and male brooders recognized as in the spermiation stage (15). A quarantine period before the start of the study ensured the absence of disease in the fish. Furthermore, fish were allowed to acclimatise to the laboratory conditions for 7 days prior to mucus collection in aerated fiber glass tanks (with $2000 \mathrm{~L}$ capacity). Fish were fed with commercial diet (Mazan, Iran) at a rate of $2 \%$ body weight day ${ }^{-1}$ three times a day.

\section{Mucus collection}

Mucus samples were collected from individuals from each sex following previously described protocol (3). Briefly, after being kept $24 \mathrm{~h}$ without feeding, 20 males and 20 females were randomly netted, individually placed in a bathtub tank and anesthetized with clove powder $(150 \mathrm{mg} / \mathrm{L})$. Mucus was scraped from the anterior to posterior direction on dorsal body surface using a sterile spatula. Mucus was not collected in the ventral side to avoid anal and sperm contamination. The collected mucus were thoroughly mixed with equal quantity of sterilized physiological saline $(0.85 \% \mathrm{NaCl})$ and centrifuged $\left(30,000 \times \mathrm{g}, 4{ }^{\circ} \mathrm{C}\right.$, 30 min) (Beckman coulter, Avanti J-26 XPI, Brea, CA, USA). Supernatant was then collected, filtered with Whatman No.1 filter paper and kept frozen at $-70{ }^{\circ} \mathrm{C}$ to avoid bacterial growth and degradation until used. After mucus collection, the fish were released in Shirood river.

\section{Microbial strains}

In vitro bactericidal activity of Caspian kutum skin mucus was examined against five bacterial strains including: Streptococcus. iniae (ATCC29178), Yersinia ruckeri (KC291153), Staphylococcus aureus (ATCC25923), Listeria. monocytogenes (ATCC1143), Pseudomonas aeruginosa (ATCC27583) and Escherichia coli 
(PTCC 1037). These bacterial strains were obtained from the Persian Type Culture Collection, which were prepared as lyophilized stocks. Furthermore, antifungal activity of skin mucus was determined against four fungi: Saprolegnia sp., Fusarium solani, Candida albicans (PTCC1023) and Aspergillus flavus. Fungal strains were obtained from Department of Aquatic Animal Health and Diseases, Research Organization of Caspian Sea.

Selective bacterial and fungal cultures were grown in Tryptic soy Agar (TSA) and PDA (Potato Dextrose Agar) medium, respectively for $24 \mathrm{~h}$ at $37^{\circ} \mathrm{C}$, then, pure colonies with $2-3 \mathrm{~mm}$ diameter were diluted in $2.5 \mathrm{ml}$ of appropriate liquid culture medium and cultured for $18 \mathrm{~h}$ at $25^{\circ} \mathrm{C}$.

\section{Antimicrobial assay}

The disc diffusion method as described by Subramanian et al. (16) was used to determine the growth inhibition effect of skin mucus extract of Caspian kutum on selective microbial collection.

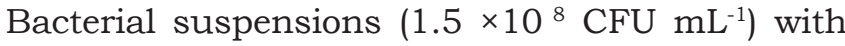
McFarland Standard $0.5 \%$ were inoculated in Mueller-Hinton agar medium with the help of sterile cotton swabs. For fungal studies, PDA medium was dispensed in Petri plates for different strains of fungi. Whatman No. 1 filter paper discs with $4 \mathrm{~mm}$ diameter were impregnated with different known amount of test skin mucus while sterile paper disc and standard antibiotic discs were applied as negative and positive controls, respectively. The impregnated discs along with the controls were kept on agar plates, previously seeded with test bacterial and fungal cultures, separately. The bacterial plates were incubated for $24 \mathrm{~h}$ at $37{ }^{\circ} \mathrm{C}$ while the fungal plates were incubated for 72-96 $\mathrm{h}$ at $30{ }^{\circ} \mathrm{C}$ to reveal any antimicrobial activity. The antimicrobial activities were determined by measuring the diameter of zone of inhibition in $\mathrm{mm}$. All tests were performed in triplicate in order to confirm the reproducible results.

Minimum inhibitory concentration (MIC) and minimum bactericidal concentration (MBC)

Mucus extracts that showed antimicrobial activity was further subjected to the test of minimum inhibitory concentration (MIC). The MIC is defined as the lowest concentration of the mucus extract of Caspian kutum at which the microorganism does not demonstrate visible growth. MIC test for bacteria was carried out by using broth microdilution method as described by Wei et al. (17). Briefly, mucus samples were serially two-fold diluted with $100 \mu \mathrm{l}$ of MuellerHinton broth (Difco Laboratories, Detroit, MI, USA) in order to determine the MIC. Fifty $\mu 1$ of this inoculum was then added into each tube containing different concentrations of mucus samples and/or Enrofloxacin (positive control) and then the samples were incubated for 16 to 24 $\mathrm{h}$ at $37{ }^{\circ} \mathrm{C}$. Growth inhibition was monitored by visual inspection of the turbidity of the mixture. After incubation the MIC was determined by the lowest concentration of the mucus extract of Caspian kutum at which the microorganism did not demonstrate visible growth. Ten $\mu \mathrm{L}$ of MIC and higher concentrations were reinoculated to each blood agar plates and incubated for $24 \mathrm{~h}$ at $25^{\circ} \mathrm{C}$. The MBC was defined as the lowest concentration of the mucus extract at which incubated microorganisms are completely killed (17).

\section{Minimum fungicidal concentration (MFC)}

Determination of MFC for fungal collection was carried out following the method described by Hellio et al. (18). Briefly, fungal suspension (2 $\times 10^{8} \mathrm{CFU} \mathrm{m} / \mathrm{L}$ ) were placed in a liquid medium consisting of RPMI 1640 (with L-glutamine buffered to $\mathrm{pH} 7.0$ with 0.165 MOPS buffer) and various known concentrations of skin mucus or ketoconazole (positive control). Fungal cultures were then incubated at $30{ }^{\circ} \mathrm{C}$ for $24 \mathrm{~h}$ and $\mathrm{MFC}$ values were recorded.

\section{Evaluation of enzyme activities}

Alkaline phosphatase, lysozyme, protease and esterase activities were determined in skin mucus samples. Alkaline phosphatase activity was estimated using Pars Azmoon kit (Tehran Company, Iran) and absorbance was read at 405 $\mathrm{nm}$ with an spectrophotometer (19).

Lysozyme activity was determined based on the method described by Ellis (20) with slight modifications. Briefly, aliquots of $50 \mu \mathrm{L}$ of mucus samples were added to $2 \mathrm{ml}$ of a suspension of Micrococcus lysodeikticus (Sigma, St Louis, MO, USA) $(0.2 \mathrm{mg} \mathrm{m} / \mathrm{L}$ in a $0.05 \mathrm{M}$ sodium phosphate buffer ( $\mathrm{pH}$ 6.2) and absorbance was measured at $450 \mathrm{~nm}$ after $0.5 \mathrm{~min}$ and $3 \mathrm{~min}$ in 
a spectrophotometer (Biophotometer, Eppendorf). One unit of lysozyme activity was defined as a reduction in absorbance of 0.001 per min. The units of lysozyme present in skin mucus were obtained from a standard curve made with hen egg white lysozyme (HEWL, Sigma) and the results were expressed as $\mathrm{U} \mathrm{mg}^{-1}$ mucus or serum proteins.

Finally, protease and esterase activities were determined using the methods described by Sheikhzadeh et al. (21). The absorbance was measured continuously for $2 \mathrm{~h}$ at $405 \mathrm{~nm}$ by ELISA reader. The activity was defined as the amount of enzyme required to release $1 \mu \mathrm{mol}$ of para-nitrophenyl product in $60 \mathrm{~s}$.

\section{Statistical Analysis}

The data were subjected to statistical analysis using the SPSS software version no. 20 (SPSS Inc., Chicago, IL, USA). Differences between both sexes were determined by one-way analysis of variance (ANOVA) followed by Duncan's multiple range test. $P$ value of $<0.05$ was considered statistically significant.

\section{Results}

\section{Bactericidal activity}

The growth of all the tested bacteria was affected by the incubation with skin mucus of Caspian kutum. The in vitro bactericidal activity of skin mucus of Caspian kutum against selective microbial collection is shown in Table 1. Zones of inhibition for female fish mucus were a little higher $(17.4 \mathrm{~mm}, 25.4 \mathrm{~mm}, 25.1 \mathrm{~mm}, 24.0 \mathrm{~mm}$, $18.4 \mathrm{~mm}$ and $22.6 \mathrm{~mm}$ ) than those observed for mucus from male specimens $(16.2 \mathrm{~mm}, 23.2 \mathrm{~mm}$, $24.7 \mathrm{~mm}, 24.3 \mathrm{~mm}, 16.7 \mathrm{~mm}$ and $20.2 \mathrm{~mm}$ ) for the same bacterial species $(p<0.05)$.

Maximum antibacterial activity was observed against $Y$. ruckeri $(24.7 \mathrm{~mm})$ and $P$. aeruginosa $(25.4 \mathrm{~mm})$, respectively in male and female fish. This was followed by E. coli $(24 \mathrm{~mm}), P$. aeruginosa $(23 \mathrm{~mm})$, L. monocytogenes $(22 \mathrm{~mm})$ and $S$. aureus $(18 \mathrm{~mm})$. While the minimum bactericidal activity was observed against $S$. iniae incubated with mucus from either male or female specimens (16.2 $\mathrm{mm}$ and $17.4 \mathrm{~mm}$, respectively) (Table 1). In addition, minimum inhibitory concentration test showed that minimum concentrations of mucus ranged between 125 to $500 \mu \mathrm{g} \mathrm{l}^{-1}$ were able to inhibit the growth of the selected bacterial and fungal pathogens.

\section{Fungicidal activity}

Similarly to the previous results described for the bacteria, the growth of all the tested fungi was also affected by the incubation with skin mucus of Caspian kutum (Table 2). The highest antifungal activity of skin mucus of Caspian kutum was observed against $F$. solani with $19 \mathrm{~mm}$ diameter of inhibition zone, followed by Saprolegnia sp. (17 $\mathrm{mm}$ ) and $A$. flavus (16 $\mathrm{mm})$. On the contrary, the minimum antifungal activity was observed against C. albicans (14 $\mathrm{mm}$ ) (Table 2).

\section{Enzymes activities}

No significant differences were observed in the mucus alkaline phosphatase, protease and esterase activities between male and female fish specimens $(p>0.05) \quad($ Table 3$)$. Curiously, only higher lysozyme activity was detected in the mucus of female fish in comparison to the values recorded on mucus from male specimens ( $p$ $<0.05$ ).

\section{Discussion}

In the present work, the antimicrobial activity of skin mucus of Caspian kutum was studied against common fish pathogens. The studied microorganisms were selected because they cause infections and mortalities on eggs, larvae and juvenile specimens of Caspian kutum (12). Our results suggest that antimicrobial components are present in the skin mucus. All bacteria and fungi tested in the current study presented more sensitivity to the skin mucus samples than that of the control antibiotics. The resulting zones of inhibition for control (Enrofloxacin) against Streptococcus, Pseudomonas, Yersinia, Escherichia, Staphylococcus and Listeria species, were $13 \mathrm{~mm}, 16 \mathrm{~mm}, 17 \mathrm{~mm}, 15 \mathrm{~mm}, 13 \mathrm{~mm}$ and $17 \mathrm{~mm}$, respectively. For the same bacterial species, zones of inhibition for female fish mucus were always a little higher than those observed for mucus from male specimens. The obtained 
Table 1: Bactericidal activities of skin mucus of Caspian kutum. MIC, minimum inhibitory concentration; MBC, minimum bacteriocidal concentration

\begin{tabular}{|c|c|c|c|c|c|c|}
\hline \multirow{2}{*}{ Bacterial strains } & \multicolumn{4}{|c|}{ Zone of inhibition (mm) } & \multirow{2}{*}{$\begin{array}{c}\text { MIC } \\
(\mu \mathrm{g} / \mathrm{mL})\end{array}$} & \multirow{2}{*}{$\begin{array}{c}\text { MBC } \\
(\mu \mathrm{g} / \mathrm{mL})\end{array}$} \\
\hline & $\begin{array}{l}\text { Sex } \\
\text { Male }\end{array}$ & Female & $\begin{array}{l}\text { Positive control } \\
\text { (Enrofloxacin) }\end{array}$ & $\begin{array}{l}\text { Negative } \\
\text { control }\end{array}$ & & \\
\hline Streptococcus iniae & $16.2 \pm 0.9^{\mathrm{b}}$ & $17.4 \pm 1.1^{\mathrm{b}}$ & $13 \pm 0.9^{\mathrm{a}}$ & 0 & $>500$ & 1000 \\
\hline Pseudomonas aeruginosa & $23.2 \pm 1.4^{\mathrm{b}}$ & $25.4 \pm 1.5^{\mathrm{c}}$ & $16 \pm 0.7^{\mathrm{a}}$ & 0 & 250 & 500 \\
\hline Yersinia ruckeri & $24.7 \pm 2.1^{\mathrm{b}}$ & $25.1 \pm 2.5^{\mathrm{b}}$ & $17 \pm 0.8^{\mathrm{a}}$ & 0 & 125 & 250 \\
\hline Escherichia coli & $24.3 \pm 1.9^{\mathrm{b}}$ & $24.0 \pm 1.8^{\mathrm{b}}$ & $15 \pm 0.7^{\mathrm{a}}$ & 0 & 125 & 250 \\
\hline Staphylococcus aureus & $16.7 \pm 1.2^{\mathrm{b}}$ & $18.4 \pm 1.5^{c}$ & $13 \pm 0.6^{a}$ & 0 & 500 & 750 \\
\hline Listeria monocytogenes & $20.2 \pm 1.3^{\mathrm{b}}$ & $22.6 \pm 1.7^{\mathrm{c}}$ & $17 \pm 1.1^{\mathrm{a}}$ & 0 & 250 & 500 \\
\hline
\end{tabular}

*Data are mean $\pm \mathrm{SD}(\mathrm{n}=20)$. Those within a row superscripted by different letters are significantly different $(p<0.05)$.

Table 2: Antifungal activities of skin mucus of Caspian kutum. MIC, minimum inhibitory concentration; MFC, minimum fungicidal concentration.

\begin{tabular}{|c|c|c|c|c|c|c|}
\hline \multirow[t]{3}{*}{ Fungal pathogens } & \multicolumn{4}{|c|}{ Zone of inhibition $(\mathrm{mm})$} & \multirow{3}{*}{$\begin{array}{c}\mathrm{MIC} \\
(\mu \mathrm{g} / \mathrm{mL})\end{array}$} & \multirow{3}{*}{$\begin{array}{c}\mathrm{MFC} \\
(\mu \mathrm{g} / \mathrm{mL})\end{array}$} \\
\hline & \multicolumn{2}{|c|}{ Sex } & \multirow{2}{*}{$\begin{array}{l}\text { Positive control } \\
\text { (Ketoconazole) }\end{array}$} & \multirow{2}{*}{$\begin{array}{l}\text { Negativ } \\
\text { e control }\end{array}$} & & \\
\hline & Female & Male & & & & \\
\hline Saprolegnia sp. & $17.0 \pm 0.8^{\mathrm{b}}$ & $18.9 \pm 1.1^{\mathrm{c}}$ & $13 \pm 0.5^{a}$ & 0 & $>125$ & 250 \\
\hline Fusarium solani & $19.2 \pm 1.2^{\mathrm{b}}$ & $18.6 \pm 0.9^{b}$ & $14 \pm 0.8^{a}$ & 0 & 125 & 250 \\
\hline Aspergillus flavus & $16.1 \pm 0.8^{\mathrm{b}}$ & $16.5 \pm 0.9^{\mathrm{b}}$ & $11 \pm 0.6^{\mathrm{a}}$ & 0 & $>250$ & 500 \\
\hline Candida albicans & $14.2 \pm 0.6^{\mathrm{b}}$ & $14.5 \pm 0.7^{\mathrm{b}}$ & $10 \pm 0.4^{\mathrm{a}}$ & 0 & 500 & 1000 \\
\hline
\end{tabular}

*Data are mean $\pm \mathrm{SD}$. Those within a row superscripted by different letters are significantly different $(p<0.05)$.

Table 3: Enzyme activities in skin mucus samples of Caspian kutum

\begin{tabular}{lcc}
\hline Enzyme & Male & Female \\
\hline Alkaline phosphatase (IU /L) & $73.58 \pm 4.2^{\text {a }}$ & $73.86 \pm 4.8^{\mathrm{a}}$ \\
\hline Lysozyme (IU/ mg) & $22.72 \pm 0.34^{\mathrm{a}}$ & $25.28 \pm 0.58^{\mathrm{b}}$ \\
\hline Protease (IU/ mg) & $30.94 \pm 2.3^{\mathrm{a}}$ & $31.12 \pm 0.16^{\mathrm{a}}$ \\
\hline Esterase (IU/ mg) & $2.94 \pm 0.08^{\mathrm{a}}$ & $3.20 \pm 0.12^{\mathrm{a}}$ \\
\hline
\end{tabular}

*Data are mean \pm SD $(\mathrm{n}=20)$. Those within a row superscripted by different letters are significantly different $(p<0.05)$. IU: International unit. 
results agree with the findings of Ghafoori et al. (4) denoting significant higher total protein in the skin mucus of female fish than male fish. However, future studies should demonstrate what specific proteins or molecules are responsible of the differences of antibacterial activity detected in the mucus of both sexes.

Compared to the results obtained from previous studies, the current work underline that the microbicidal activity present in mucus vary among the fish species, even for the same bacteria. In this sense, Kuppulakshmi et al. (24) reported high antibacterial activity against ten pathogenic bacteria in skin mucus of Channa punctatus. They reported an inhibition zone diameter $25 \mathrm{~mm}$ for $S$. aureus which is higher compared to our finding $(18 \mathrm{~mm})$. However, in agreement to our results, similar antibacterial activity against Pseudomonas aeruginosa (24 $\mathrm{mm}$ ) was reported (24). Conversly, lower antibacterial activity was demonstrated in the mucus of $C$. punctatus against $S$. aureus (inhibition zone diameter $8.75 \mathrm{~mm}$ compared with inhibition zone diameter $24 \mathrm{~mm}$ in our study). Interestingly, no bactericidal activity was observed against the $E$. coli and $P$. aeruginosa bacterial strains in the skin mucus of the freshwater fishes, Rita rita and Channa punctatus (27).

Previous findings confirm that the antibacterial activity in fish skin mucus differ from fish species to species and even that can be specific toward certain bacteria (22). However, one reason for different results obtained in different studies may be due, at least in part to the type and the concentration of solvents used in mucus extraction.

In fact, some studies revealed that the antimicrobial activity of fish mucus extract is higher in acidic solvents (e.g. in $0.1 \%$ trifluoroacetic acid or $3 \%$ acetic acid) than that crude extracts or in aqueous medium $(16,17,28)$.

Skin mucus of Caspian kutum specimens tested in the present work also presented highest antifungal activity against $F$. solani $(19.2 \mathrm{~mm})$ and Saprolegnia sp. $(18.9 \mathrm{~mm})$ in mucus from male and female fish specimens, respectively. On the contrary, this fungicidal activity was lowest against the A. flavus $(14.2 \mathrm{~mm})$ and C. albicans $(14.5 \mathrm{~mm})$ in skin mucus of male and female fish specimens, respectively. Balasubramanian et al. (3) demonstrated that epidermal mucus of Indian carps (Catla catla, Labeo rohita, and Mugil cephalus) showed the higher antifungal activity than that of exotic Chinese carps such as Ctenopharyngodon idella and Hyphophthalmichthys molitrix while mucus of $M$. cephalus presented moderate antifungal activity in all the tested fungi. Very similar to our findings were observed against $A$. flavus and $C$. albicans in epidermal mucus from C. catla and L. rohita (3).

Curiously, Ikram and Ridzwan (29) only find antifungal activity in water extract of fish skin mucus whereas the PBS extracts and even the pure mucus failed to produce any positive result. A possible explanation for these results was based on the fact that the extracts obtained using higher polarity solvents were more effective radicalscavengers and microbial inhibitors than were those obtained using less polar solvents (29).

The antifungal activity of mucus from fish might be due to different mechanisms such as pore formation or disruption of fungal cell membrane in salt dependent and energy independent situations, or to the formation of reactive oxygen species depletion or binding to a receptor on the fungal cell membrane (3). On the other hand, the antifungal activity of anti-microbial peptides (very abundant on fish mucus) are due to the inhibition of germination of conidia or inhibition of chitin synthesis (28).

In the present study, the results of MIC determination showed that minimum concentrations of aqueous extract of mucus ranged between 125 to $500 \mu \mathrm{g} \mathrm{L}^{-1}$ was able to inhibit the growth of the bacterial and fungal pathogens tested. Our results about MIC values are very similar to others obtained when using mucus extracts to inhibit the growth of E. coli, $P$. aeruginosa and $S$. aureus $(17,18)$.

Different enzymes with a putative antimicrobial effect (such as lysozyme, protease, esterase and alkaline phosphatase) have been identified in several fish species including Caspian kutum (4).

In the present study, the presence of alkaline phosphatase, lysozyme, protease and esterase activities as antibacterial agents were studied on mucus from males and females specimens and some variations were observed among them and perhaps, these differences also contribute to the differences observed between the bactericidal activities recorded (30). However, among the studied enzymes, only lysozyme presented significantly higher activity in the mucus of females, when compared with the activity found in mucus of males. Lysozyme is believed to be the most powerful bacteriolytic protein since it has 
the ability to cleave the bacterial peptidoglycan $(31,32)$. Due to the multiple effects known of such important enzyme in fish, we postulate the implication of this enzyme to the overall higher antimicrobial effect observed in the skin mucus of Caspian kutum females. In accordance with present data, higher lysozyme activity was also recorded in skin mucus of female Caspian kutum (respect to the values found on males) during reproductive period. Authors related the observed differences to environmental (seasonal temperature) and physiological (reproductive activity and migration) conditions (4).

In overall, the observed dissimilarities in the antimicrobial activity of fish skin mucus seen in the different studied species may be due, at least in part, to the great variation in the quality and quantity of mucus composition among fish species that cause different anti-bacterial and anti-fungal effects. These differences, in addition to the impact of genetic factors related to fish species, can also be caused by age, sex, nutritional impact and environmental factors or even differences in laboratory protocols or conditions of sample storages $(4,22,31,33-35)$. Furthermore, the denoted variation in the antimicrobial activity of skin mucus in the same fish species, against different pathogens, inhabiting different geographical regions could be due to diverse ecological and physiological conditions (27).

\section{Conclusion}

Diverse studies on innate immunity in fish have demonstrated that fish epidermal mucus can inhibit the growth of some bacteria and fungi, therefore may have a potential source of novel antimicrobial components $(3,17,18,23)$. The mechanism by which antimicrobial substances in fish mucus kill microbes are still unclear, but it is currently thought that different peptides involved in such activities could employ different strategies. These include the fatal depolarization of the cell membrane (25), cytoplasmic membrane disruption, pore or channel formation (26, $27)$ or inhibition of cell wall and nucleic acid synthesis (26). Independently of the isolated effector molecules and the mechanisms involved in the microbial killing, the measurement of the microbicidal activity is a very realistic approximation. Therefore, the current research demonstrated the antimicrobial activities of epidermal mucus from Caspian kutum. Higher lysozyme activity and antimicrobial activities was recorded in the mucus of female fish in comparison to the values recorded on male fish specimens. As a result, skin mucus of this fish species (especially from female specimens) could be considered as a potential source of newer and more effective antibacterial components. Further studies are needed to purify, fractionate and characterize those antimicrobial compounds from the mucus of Caspian kutum.

\section{Acknowledgements}

We wish to thank Dr Aliasghar Saeedi and Dr Armin Abedian Amirifor their kind assistance during this study. This work was partly supported by the Spanish Ministry of Economy and Competitiveness co-funded with Fondos Europeos de Desarrollo Regional/European Regional Development Funds (Grant no. AGL2014-51839-C5-1-R) and Fundación Séneca de la Región de Murcia (Grupo de Excelencia. Grant no. 19883/GERM/15). The authors declare no potential conflict of interests.

The authors contributed equally to the manuscript

\section{References}

1. Kanno T, Naka T, Muroga K. Mode oftransmission of vibriosis among ayu Plecoglossus altivelis. J Aquat Anim Health 1989; 1: 2-6.

2. Austin B, McIntosh D. Natural antibacterial compounds on the surface of rainbow trout, Salmo gairdneri Richardson. J Fish Dis 1988; 11: 275-7.

3. Balasubramanian S, Gunasekaran G, Baby Rani P, Arul Prakash A, Prakash M, Senthil Raja JAP. A study on the antifungal properties of skin mucus from selected fresh water fishes. Golden Res Thought 2013; 2: 23-9.

4. Ghafoori Z, Heidari B, Farzadfar F, Aghamaali M. Variations of serum and mucus lysozyme activity and total protein content in the male and female Caspian kutum (Rutilus frisii kutum, Kamensky 1901) during reproductive period. Fish Shellfish Immunol 2014; 37: 139-46.

5. Lemaitre C, Orange N, Saglio P, Gagnonand Molle G. Characterization and ion channelof novel antibacterial proteins from the skin mucous of 
carp (Cyprinus carpio). Eur J Biochem 1996; 240: 123-49.

6. Fouz B, Devesa S, Gravningen K, Barja JL, Toranzo AE. Antibacterial action of the mucus of turbot. Bull Eur Assoc Fish Pathol 1990; 10: 56-9.

7. Iranian Fisheries Organization (IFO). Exploitation of sturgeon fish stock in 2015. Teheran : IFO, 2015: 25-8.

8. Azarin H, Aramli MS, Imanpour MR, Rajabpour M. Effect of a probiotic containing Bacillus licheniformis and Bacillus subtilis and ferroin solution on growth performance, body composition and haematological parameters in Kutum (Rutilus frisii kutum) fry. Prob Antimicrob Protein 2015; 7 : 31-7.

9. Hoseinifar SH, Sharifian M, Vesaghi MJ, Khalili M, Esteban MÁ. The effects of dietary xylooligosaccharide on mucosal parameters, intestinal microbiota and morphology and growth performance of Caspian white fish (Rutilus frisii kutum) fry. Fish Shellfish Immunol 2014; 39: 231-6.

10. Hoseinifar SH, Zoheiri F, Dadar M, Rufchaei R, Ringø E. Dietary galactooligosaccharide elicits positive effects on non-specific immune parameters and growth performance in Caspian white fish (Rutilus frisii kutum) fry. Fish Shellfish Immunol 2016; 56: 467-72

11. Hoseinifar SH, Zoheiri F, Caipang CM. Dietary sodium propionate improved performance, mucosal and humoral immune responses in Caspian white fish (Rutilus frisii kutum) fry. Fish Shellfish Immunol 2016; 55: 523-8

12. Adel M, Abedian Amiri A, Zorriehzahra J, Nematolahi A, Esteban MÁ. Effects of dietary peppermint (Mentha piperita) on growth performance, chemical body composition and hematological and immune parameters of fry Caspian white fish (Rutilus frisii kutum). Fish Shellfish Immunol 2015; 45:841-7.

13. Guardiola FA, Cuesta A, Abellán E, Meseguer J, Esteban MA. Comparative analysis of the humoral immunity of skin mucus from several marine teleost fish. Fish Shellfish Immunol 2014; 40: 24-31.

14. Guardiola FA, Cuesta A, Arizcun M, Meseguer J, Esteban MA. Comparative skin mucus and serum humoral defence mechanisms in the teleost gilthead seabream (Sparus aurata). Fish Shellfish Immunol 2014; 36:545-51.

15. Kesteven GL. Manual of field methods in fisheries biology. FAO Manuals in Fisheries Science No 1. Rome : FAO, 1960: 152.
16. Subramanian US, Mackinnon SL, Ross NW. A comparative study on innate immune parameters in the epidermal mucus of various fish species. Comp Biochem Physiol 2007; 148: 256-63.

17. Wei OY, Xavier R, Marimuthu K. Screening of antibacterial activity of mucus extract of Snakehead fish, Channa striatus (Bloch). Eur Rev Med Pharmacol Sci 2010; 14: 675-81.

18. Hellio C, Pons A, Beaupoil MC, Bourgougnon N, Legal Y. Antibacterial, antifungal and cytotoxic activities of extracts from fish epidermis and epidermal mucus. Int $\mathrm{J}$ Antimicrob Agent 2002; 20: 214-19.

19. Sanchooli O, Hajimoradloo A, Ghorbani R. Measurement of alkaline phosphatase and lysozyme enzymes in epidermal mucus of different weights of Cyprinus carpio.World J Fish Marine Sci 2012; 4: 521-4.

20. Ellis AE. In: Stolen JS, Fletcher TC, Anderson DP, et al, eds. Lysozyme assay in techniques in fish immunology. Fair Haven, New Jersey : SOS Publications, 1990: 101-3.

21. Sheikhzadeh N, Heidarieh M, Karimi Pashaki A, Nofouzi K, Ahrab Farshbafi M, Akbari M. Hilyses, fermented Saccharomyces cerevisi$a e$, enhances the growth performance and skin non-specific immune parameters in rainbow trout (Oncorhynchus mykiss). Fish Shellfish Immunol 2012; 32: 407-10.

22. Noya M, Magarinos B, Toranzo AE, Lamas J. Sequential pathology of experimental pasteurellosis in gilthead seabream Sparus aurata a light microscopic and electron microscopic study. Dis Aquat Org 1995; 21: 177-86.

23. Esteban MA. An overview of the immunological defenses in fish skin. ISRN Immunol 2012; 2012(ID 853470): e1-29. https://www.hindawi. com/journals/isrn/2012/853470 (June 2017)

24. Kuppulakshmi C, Prakash M, Gunasekaran G, Manimegalai G, Sarojini S. Antibacterial properties of fish mucus from Channa punctatus and Cirrhinus mrigala. Eur Rev Med Pharmacol Sci 2008; 12: 149-53.

25. Westerhoff HV, Juretic D, Hendler RW, Zasloff M. Magainins and the disruption of membrane- linked free-energy transduction. Proc Natl Acad Sci U S A 1989; 86: 6597-601.

26. Yang JY, Shin SY, Lim SS, Hahm KS, Kim Y. Structure and bacterial cell selectivity of a fish derived antimicrobial peptide, pleurocidin. J Microbiol Biotechnol 2000; 16: 880-8.

27. Kumari U, Nigam AK, Mittal S, Mittal AK. 
Antibacterial properties of the skin mucus of the freshwater fishes, Rita rita and Channa punctatus. Eur Rev Med Pharmacol Sci 2011; 15: 781-6.

28. Rodrigues E, Dobroff S, Taborda P, Travassos R. Antifungal and antitumor models of bioactive protective peptides. An Acad Bras Cienc 2009; 81: 503-20.

29. Ikram NM, Ridzwan BH. A preliminary screening of antifungal activities from skin mucus extract of Malaysian local swamp eel (Monopterus albus). Int Res J Pharm Pharmacol 2010; 3(1): e1-8. https://www.interesjournals.org/articles / a-preliminary-screening-of-antifungal-activities-from-skin-mucus-extract-of-malaysian-local-swamp-eel-monopterus-albus.pdf (June 2017)

30. Fast MD, Sims DE, Burka JF, Mustafa A, Ross NW. Skin morphology and humoral non specific defense parameters of mucus and plasma in rainbow trout, coho and Atlantic salmon. Comp Biochem Physiol 2002; 132: 645-57.

31. Yano T. Non-specific immune system: humoral defense. In: Iwama G, Nakanishi T, eds. The fish immune system: organism, pathogen, and environment. San Diego : Academic Press, 1996: 106-59.

32. Saurabh Sh, Sahoo P K. Lysozyme: an important defence molecule of fish innate immune system. Aquacult Res 2008; 39: 223-39.

33. Schrock RM, Smith SD, Maule G, Doulos SK, Rockowski JJ. Mucous lysozyme levels in hatchery coho salmon (Oncorhynchus kisutch) and spring Chinook salmon (O. tshawytscha) early in the parr-smolt transformation. Aquaculture 2001; 198: 169-77.

34. Balfry SK, Iwama GK. Observation on the inherent variability of measuring lysozyme activity in coho salmon (Oncorhynchus kisutch). Comp Biochem Physiol 2004; 138: 207-11.

35. Caruso G, Denaro MG, Caruso R, Manchini F, Genovese L, Maricchiolo G. Response to short term starvation of growth, haematological, biochemical and non-specific immune parameters in European sea bass (Dicentrarchus labrax) and blackspot sea bream (Pagellus bogaraveo). Mar Environmen Res 2011; 72: 46-52.

\title{
PROTIBAKTERIJSKA AKTIVNOST IN ENCIMI V VZORCIH SLUZI KOŽE SAMCEV IN SAMIC KASPIJSKEGA KUTUMA (Rutilus frisii kutum Kamensky, 1901)
}

\author{
M. Adel, R. Safari, S. Soltanian, M. J. Zorriehzahra, M. Á. Esteban
}

Povzetek: Sloj sluzi, ki pokriva površino rib, vsebuje veliko količino protimikrobnih spojin, kizagotavljajo prvo obrambo pred škodljivimi mikroorganizmivvodi. V študiji je bila testirana baktericidna aktivnost sluzi s površine kože kaspijskega kutuma (Rutilus frisii kutum) na šestih patogenih bakterijskih sevih (Streptococcus iniae, Yersinia ruckeri, Staphylococcus aureus, Listeria monocytogenes, Pseudomonas aeruginosain Escherichia coll). Ocenjena je bila tudi fungicidna aktivnost proti štirim patogenem vrstam gliv (Saprolegnia sp., Fusarium solani, Candida albicans in Aspergillus flavus). Največja in najmanjša protibakterijska aktivnost je bila opažena proti Y. ruckeri in $S$. iniae, medtem ko je bila pri $F$. solani in $C$. albicans odkrita največja in najmanjša fungicidna aktivnost. Zanimivo je, da je bila protimikrobna aktivnost višja pri sluzi samic kot pri sluzi samcev. Minimalni zaviralni preizkus koncentracije je pokazal, da so najmanjše koncentracije sluzi, ki so zavirale rast izbranih bakterijskih in glivičnih patogenov med 125 do $500 \mu \mathrm{g} / \mathrm{L}$. V vzorcih sluzi so bili proučevani tudi aktivnosti alkalne fosfataze, lizocima, proteaz in esteraz. Privečini meritev ni bilo razlik med spoloma, le pri aktivnosti lizocima je bila ta aktivnost višja v sluzi samic v primerjavi z vrednostmi, izmerjenimi v vzorcih samcev. Kožna sluznica te vrste rib (zlasti samic) bi lahko bil potencialni vir novih in učinkovitejših antibakterijskih sredstev.

Ključne besede: Rutilus frisii kutum; kožna sluznica; baktericidna aktivnost; proti glivično delovanje; ribe 